Article

\title{
Wind Power Development in China: An Assessment of Provincial Policies
}

\author{
Xiaogang Zhang ${ }^{1}$, Dong Wang ${ }^{2}$, Yuanhao Liu ${ }^{3}$ and Hongtao $\mathrm{Yi}^{4, *}$ \\ 1 School of Management, Xi'an University of Architecture and Technology, Xi'an 710055, China; \\ zxg100220@163.com \\ 2 Economic and Trade Department, Henan Institute of Technology, Xinxiang 453000, China; \\ guanghua911@163.com \\ 3 School of Public Policy and Management, Tsinghua University, Beijing 100084, China; liuyuan0817@sina.com \\ 4 John Glenn College of Public Affairs, The Ohio State University, Columbus, OH 43210, USA \\ * Correspondence: yi.201@osu.edu; Tel.: +1-614-247-8791
}

Academic Editor: Andrew Kusiak

Received: 29 May 2016; Accepted: 27 July 2016; Published: 29 July 2016

\begin{abstract}
Wind energy has become a fast growing industry in China in the last decade. The development of the wind energy industry presents interesting policy questions. In the context of China, in additional to national energy policies, provincial policies were designed and implemented to stimulate the growth of wind power. This paper examines factors, especially provincial wind energy policies, in driving the growth of wind power capacity in the Chinese provinces. Statistical analysis with a longitudinal data set for wind power capacity in Chinese provinces from 2001 to 2012 reveals that the adoption of wind energy policies and a general energy plan at the provincial level are having positive effects on the growth of wind capacity in Chinese provinces.
\end{abstract}

Keywords: wind power; policy designs; wind capacity; policy evaluation

\section{Introduction}

China has witnessed dramatic economic development during the last few decades, with the gross domestic product (GDP) growing at a yearly rate of approximately $10 \%$ [1]. The rapidly-growing Chinese economy is accompanied by increasing demand for energy and resources. Currently, the Chinese energy consumption structure is overly reliant on fossil fuels, leaving a negative impact on China's long-term energy sustainability-a policy issue that has captured considerable public attention.

At the same time, the environment in China has been deteriorating over the years, posing critical challenges to policy makers and citizens. Numerous environmental problems occur as byproducts of rapid urbanization and industrialization in China, among which air pollution, water pollution, and soil pollution are the typical environmental threats [2,3]. The increasing environmental awareness of Chinese citizens has pushed the Chinese government to seek alternative energy generation paths. As a reliable and affordable renewable energy option, wind energy is increasingly seen as an important part of the renewable portfolio across the globe, with fast deployment in the European Union and Unites States [4].

With a motivation to enhance environmental performance and promote green economic development [5], China has passed legislation and adopted policies in the past few years to fund wind energy research, to develop wind energy, and to elevate the contribution of wind in the power generation portfolio. Studies have been conducted to examine the passage and outcomes of the wind energy policies passed by the central government with case studies and quantitative regression analyses [6-8]. Both central and provincial governments in China have employed various renewable energy policies, especially wind policies. Studies on provincial policies are relatively rare, and they 
primarily draw conclusions from case studies, which are difficult to generalize [2]. While most of the extant research has paid much attention to the design, implementation, and effectiveness of the wind energy policy instruments adopted by the central government, few studies have investigated the nuanced rules, policies, regulations, and subsidies adopted at the provincial government level. As shown in Yi and Liu [5], provincial policies are significant drivers of the green energy economy at the local level, and the implementation of such local policies is instrumental in achieving renewable energy policy outcomes. Such gaps in extant research call for more serious attention to the role of provincial wind energy policies in stimulating the deployment of wind energy. Relevant questions include: have provincial governments adopted any policies to stimulate the deployment of wind energy capacity? If yes, how are the policies designed? Are provincial policies effective in driving the growth of installed wind capacity in Chinese provinces?

To address the above-mentioned research questions, this study is designed to examine the effectiveness of provincial clean energy policies in promoting wind energy development via quantitative panel data analysis. Specifically, this paper will quantify wind energy policies in Chinese provinces, and evaluate the influence of these policies on wind energy development in China. A detailed description of the research methods and data collection process will be provided, followed by the results and discussion, based on which several policy implications will be summarized at the end of the paper.

\section{Methods}

\subsection{Wind Power in China: A Literature Review}

In the extant literature, studies show that China's wind power industry is constrained by factors such as institutional barriers, grid integration problems, and technological weaknesses [9-13]. Firstly, the wind power industry in China is heavily controlled by state-owned enterprise, influenced by government policy decision, and characterized as an incomplete electricity market. Therefore, the development of potentially more efficient, non-grid-connected wind energy infrastructure, for example, is faced with strong institutional barriers [9]. The institutional barriers have blocked China's wind power industry from responding to system problems and adjusting efficiently. Stimulated by target-setting incentives, the extant policies in China are effective in improving the installed capacity of wind power; however, their ability to solve grid integration problems are weak [10]. This problem was not serious at the beginning, but as the installed wind power capacity rapidly grows, the grid-connected capacity in China has lagged behind [12].

The problem has recently become more severe. In fact, since 2006, the percentage of wind power generators connected to the grid in China has been continuously declining [14]. Wind power technology has advanced dramatically. An increasing number of Chinese firms have the ability to produce large-size wind turbines, with less foreign technological assistance [13]. However, China's wind power industry is still very constrained by technological weakness, especially when dealing with sophisticated problems that need world-class innovation [12].

Some studies are also concerned with the market conditions and regulations of the wind energy industry [15-21]. Lema and Ruby [17] argue that the Chinese wind turbine manufacturing industry could be divided into three phases: import phase, incremental phase, and coordinated phase. In the early two phases, the wind market was not attractive for power companies embedded in a highly uncertain and incomplete competition environment. The regulations were inefficient because of local utilities and the fragmented bureaucratic power structure. In the 2000s, the Chinese government realized the problems and took actions to bring related government departments together, to build market-based incentives and competition, and to improve regulations. This resulted in a boom of the wind energy industry. Yang et al. [18] also argue that market and regulation will influence the development of the wind energy industry. They found that uncertain policy frameworks for electricity market regulation increased the risk of investing in the wind energy industry. The net present values of 
the wind energy industry are significantly affected by uncertain clean development mechanism benefits. Zhang et al. [21] found that domestic government interventions help the wind industry grow, and they argue for further strengthening international support, such as financial support and technology transfer. Although the market-oriented reforms have been in place for decades, the presently dominant operation mechanism of the wind market is still centrally planned. There is still plenty of room for reform, and the introduction of additional market mechanisms [19]. Lam et al. [22] found that the renewable portfolio standard (RPS) and tax incentives are less important, compared with policy drivers that have a direct effect on wind developers' financial status. Since wind power deployment in China also has a great impact on the short-term tax interests of local governments, it is important to align the incentive mechanisms of local governments [23].

Nevertheless, the extant literature on wind and energy policies mainly focuses on the central government's activities and policies [11,20]; fewer studies have been conducted to assess the effects of provincial wind energy policies on advancing wind power at the provincial level. The wind energy policies involved multiple government organizations from both state and local levels, various ministries, and commissions. Liao [7] carefully differentiated 72 wind energy policies published from 20 different organizations and analyzes the evolutionary processes, but failed to further evaluate the policy effectiveness. Shen and Luo [8] analyzed the intentions and effects of five different policies, but the discussions are based on national level policies. China's wind energy industry gets benefits from decentralized policy competition, but also are hindered by fragmented provincial protectionism [10,17]. Studies have also been conducted to evaluate the potential for and effects of renewable energy development in Hong Kong. It is found that the carbon intensity for the renewable energy scenario will be reduced by $57 \%$ by 2020 [24,25]. Evaluating the province-level policies and actions is crucially important, but few studies test the effectiveness of different policies at China's province level. Zhao et al. (2016) compare the effectiveness of price policy and non-price policy with province-level panel data. This study has successfully assessed in detail the different effects between the two kinds of policy instruments, but pays no attention to other important provincial government actions, such as regulations. In the next few sections, a research design will be presented to quantify and evaluate the effectiveness of local wind policies.

\subsection{Model}

The goal of this paper is not only to analyze policies, but also to examine the economic, social, and natural factors contributing to the growth of wind energy capacity in Chinese provinces from 2001 to 2012. A fixed-effect regression model is employed to account for unobserved province-level and time variations in wind capacity. A Hausman test will be performed to test if a fixed-effect model should be chosen over a random effect model. In the study of renewable energy capacity, numerous studies have employed fixed-effect models to examine the impact of state-level renewable energy policies on renewable capacities in the United States [26-28]. Following the literature, the mathematical representation of the fixed effect model is presented as:

$$
Y_{p, t}=\alpha_{p}+\tau_{t}+\beta X_{p, t}+\varepsilon_{p, t}
$$

where " $p$ " denotes the province and " $t$ " represents the year of the observation. $Y_{p, t}$ indicates the dependent variable, log-transformed wind generation capacity in province $p$ for year $t . X_{p, t}$ are independent variables, including provincial wind policy, pollution fee collection, $\mathrm{SO}_{2}$ emissions, GDP (per capita), unemployment rate, unexplored wind potential, income (per capita), and population density; $\alpha_{p}$ denotes a province-specific intercept; $\tau_{t}$ is a vector of time dummies that take into account fixed time effect, capturing the influence of national energy policies (for example Renewable Energy Law); and $\varepsilon_{p, t}$ varies independently across provinces and over the time period. 


\subsection{Dependent Variable}

The dependent variable of this study is wind energy generation capacity in Chinese provinces from 2001 to 2012. This measure was coded from the Chinese Wind Energy Association (CWEA). Wind resources in China are more abundant in the northeast, north, and northwest, but the power load is located primarily in the coastal regions. Due to the spatial mismatch between wind resources and power load, grid integration and market absorption are gradually becoming major constraints of wind power development. As a result, the major drivers for wind power deployment are local policy and market factors, instead of energy demand from load centers in coastal provinces. As shown in Figure 1, the cumulative installed wind capacity is unevenly distributed among provinces, with Inner Mongolia, Hebei, and Gansu being the leaders in wind power development. Figure 2 provides a graphical demonstration of the geographic distribution of wind capacity among the Chinese provinces. Although most of the provinces with high installed wind capacity are located in northern China, it remains unknown whether such variation is driven by variation in policies or wind potentials. This paper will empirically analyze the underlying factors leading to the differences among provinces in wind power development.

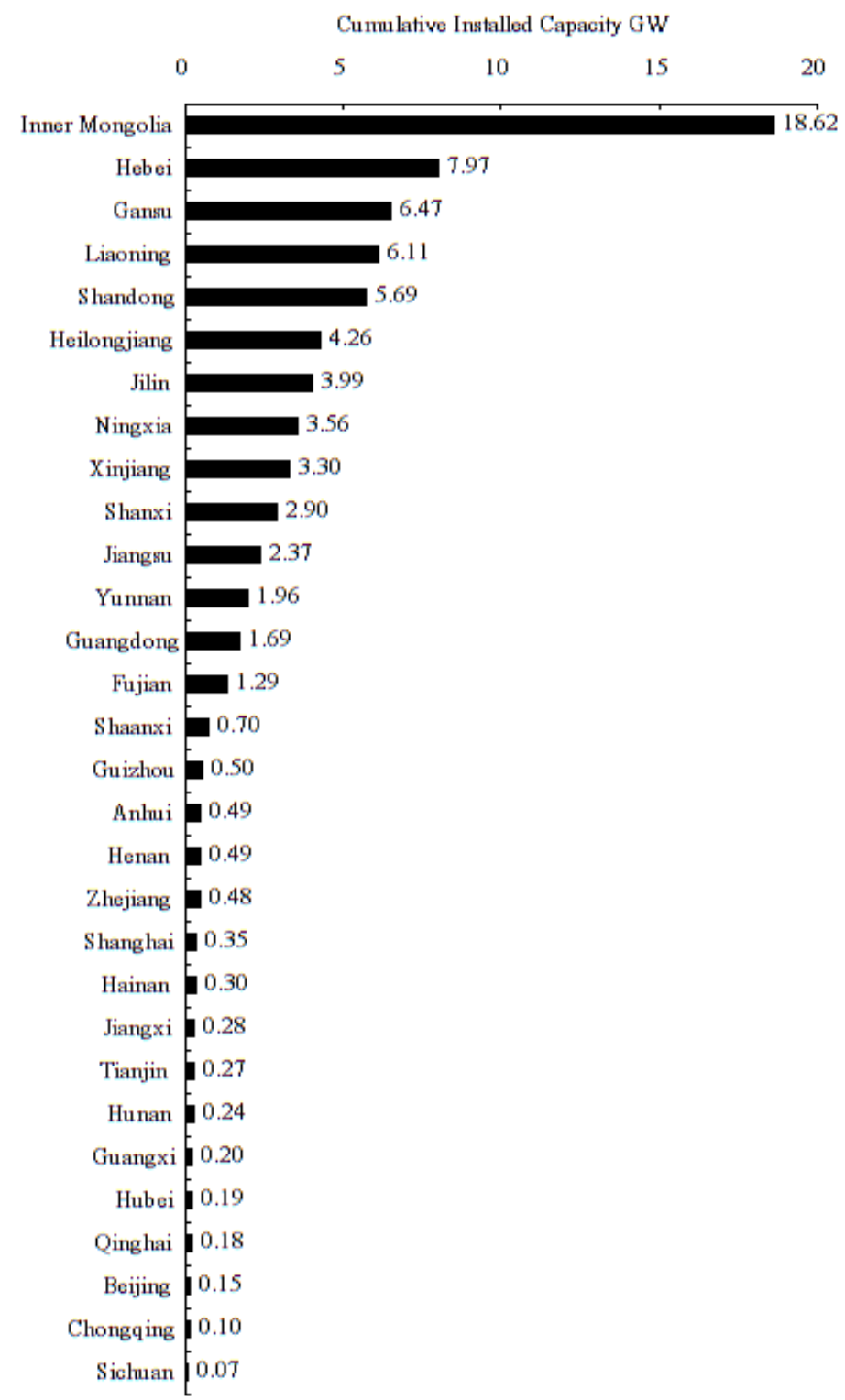

Figure 1. Cumulative Installed Wind Capacity in 2012 by Province. 


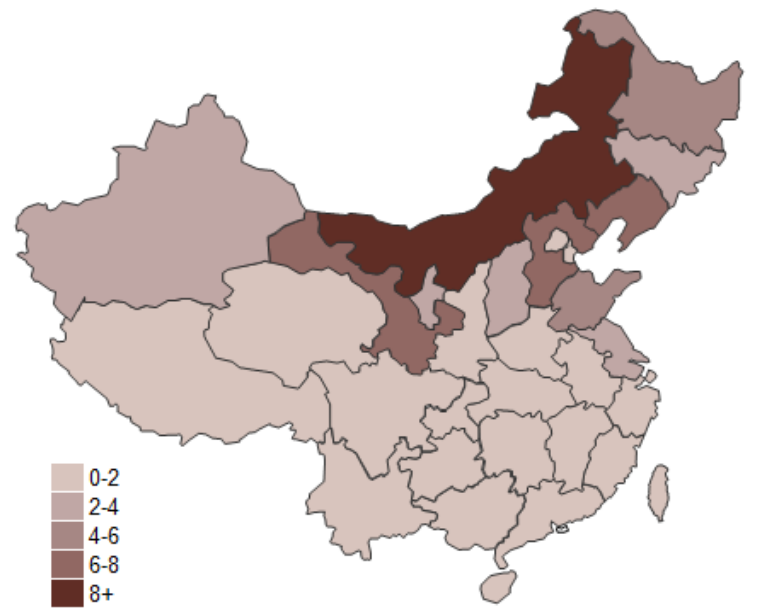

Figure 2. Geographical distribution of cumulative Installed Wind Capacity in 2012 (unit: GW).

\subsection{Provincial Wind Energy Policy and Energy Plans}

The central government plays a leading role in Chinese clean energy legislation. The renewable Energy Law in 2006 set the foundation for clean energy development in China. After the Renewable Energy Law in 2006, many new energy policies and plans were intensively enacted from 2006 to 2013 - not only at the national level, but also, more importantly, among the provinces.

As shown in Table 1, nine provinces have adopted provincial-level wind energy policies to stimulate the development of wind energy within the provincial boundaries. In the following paragraphs, we discuss and present the provincial wind energy policies for each province in detail. In Inner Mongolia, "Wind Power Development 11th "FYP" and Long-term Objectives for 2020" was implemented in 2006 (FYP: five year plan). This policy divided Inner Mongolia into 26 functional zones for wind energy development, and developed a planning goal to achieve an installed wind energy capacity by 2010. The policy placed an emphasis on developing five key projects and ten pilot projects in a few counties and towns to develop industrial bases for wind power. The policy was renewed and further developed in 2011, under the policy document named "Wind Power Development and Grid Integration 12th FYP". Hebei province developed a provincial-level plan to start the Baihuapo Wind Power Project, located in Chengde City. The planned installed wind energy capacity is $49.5 \mathrm{MW}$.

Table 1. Provincial wind energy policies and plans. FYP: five year plan.

\begin{tabular}{|c|c|c|}
\hline Province & Year & Wind Energy Policies and Plans \\
\hline \multirow{2}{*}{ Inner Mongolia } & 2006 & Wind Power Development 11th "FYP" and Long-Term Objectives for 2020 \\
\hline & 2011 & Wind Power Development and Grid Integration 12th "FYP" \\
\hline Hebei & 2011 & Baihuapo Wind Power Project \\
\hline Gansu & 2008 & Regulation for Wind Power Development and Construction Order \\
\hline Jilin & 2008 & Interim Measures of Wind Power Project Preliminary Work \\
\hline Ningxia & 2011 & Land Management Measures of Wind and Solar Photovoltaic Power Generation Project \\
\hline \multirow{2}{*}{ Xinjiang } & 2005 & Tax Exemption of Urban Land Using for Wind Power Plants \\
\hline & 2007 & Energy 11th "FYP” and Wind Power Development for 2020 \\
\hline Jiangsu & 2006 & Wind Power Development Plan from 2006 to 2020 \\
\hline Yunnan & 2004 & The Power Industry 11th "FYP" and Long-Term Objectives for 2020 \\
\hline Shanghai & 2008 & Interim Measures of Wind Power Project Preliminary Work \\
\hline Jiangxi & 2007 & New Energy Development 11th “FYP" (wind power) \\
\hline
\end{tabular}


In Gansu province, the "Regulation for Wind Power Development and Construction Order" was passed in 2008. The policy put into effect a bidding process for wind energy projects, administered centrally by the Development and Reform Commission of Gansu province. Jilin province's wind energy policy, adopted in 2008, featured the "Interim Measures of Wind Power Project Preliminary Work", which stipulated the development approach of wind energy in Jilin mainly via a bidding or delegated development process, if approved by the provincial government. Ningxia province approached policy support for wind energy through preferential land use policies, as stipulated in "Land Management Measures of Wind and Solar Photovoltaic Power Generation Project" in 2011.

The Tax Exemption of Urban Land Use for Wind Power Plants was adopted in 2005 in Xinjiang; the policy provided tax exemptions for land use taxes for wind power plants to stimulate their development and business operations. Jiangsu province developed a specialized plan for wind power development in 2006, titled "Wind Power Development from 2006 to 2020". The plan stated that Jiangsu should have an installed wind energy capacity of $1500 \mathrm{MW}$, and an industrial value of 30 billion Chinese RMB yuan for the wind manufacturing businesses. Shanghai adopted "Interim Measures of Wind Power Project Preliminary Work" in 2008, which defined the rights for wind power development mainly through a bidding process. In 2007, Jiangxi province adopted the "New Energy Development 11th FYP", which planned to have an installed wind power capacity of 100 MW by 2010 , and explore $43 \%$ of the available wind resources by 2020 .

In addition to policies targeting wind energy development, provinces have also developed strategies for overall energy development by adopting the Energy Development Plans into the provincial Five Year Plans. Provincial energy development FYPs are shown in Table 2. Sixteen provinces adopted the 11th FYP for Energy Development.

Table 2. Summary of provincial energy policies and plans.

\begin{tabular}{cc}
\hline Policies and Plans & Provinces \\
\hline Energy Development 11th “FYP” & $\begin{array}{c}\text { Inner Mongolia, Hebei, Gansu, Ningxia, Xinjiang, Shanxi, Guangdong, Anhui, } \\
\text { Henan, Shanghai, Hubei, Qinghai, Beijing, Sichuan, Shaanxi, Guizhou }\end{array}$ \\
\hline
\end{tabular}

It can be hypothesized that provincial wind energy policies and energy plans play significantly positive roles in stimulating wind energy deployment in the provinces. Given that wind energy policies are targeted solely for the development of wind generation, while energy plans cover a broader spectrum of energy sources, we can expect that wind energy policies will have a larger positive impact than general energy plans on wind power deployment.

To measure wind energy policy, a binary variable is used to indicate whether a province adopts wind energy policy in a year, with " 1 " representing that a province adopts a wind energy policy in that year, and " 0 " otherwise. In a similar way, another binary variable is created to indicate whether a province adopts an energy plan in a year, with " 1 " representing a province that adopts an energy plan in that year, and " 0 " otherwise.

\subsection{Stringency of Environment Regulation}

Wind energy development in China is not separable from its environmental regulation and governance. In a province with more effective environmental regulation, wind power industries get substantive support from the government. This measure is very similar to the measure of government ideology in terms of environmental sustainability. Thus, it is hypothesized that provinces with more stringent environmental regulation will have more wind capacity. To measure the stringency of environmental regulation, the collection of a pollution fee is used as a proxy. The data for this variable are collected from the Ministry of Environmental Protection. 


\subsection{Pollution-Intensive Interest Groups}

Pollution-intensive industries are one of the major actors that oppose the development of wind power. Thus, it can be hypothesized that the more $\mathrm{SO}_{2}$ emissions produced by the industries in a province, the slower the pace of wind energy deployment in that province will be. The data on $\mathrm{SO}_{2}$ emissions are collected from the China Statistical Yearbook [1], and this variable is measured in tens of thousands of tons.

\subsection{Economic Environment}

Two economic environment variables are taken into account. The first factor is per capita Gross Domestic Product (GDP) in the province. Per capita GDP is measured in GDP (one hundred million RMB Yuan) divided by year-end population (ten thousand persons), collected from the China Statistical Yearbook [1]. Also collected from the China Statistical Yearbook [1], the unemployment rate in the province is another important economic factor included in the analysis. The unemployment rate, measuring the local economic health, could directly influence the economic environment for wind energy industries. As shown in Yi [29], there are two possibilities. A high unemployment rate means a stagnant local economy in need of less electricity, making it harder to add more renewable capacity. Alternatively, when the unemployment rate is high, local governments are pressured to search for alternative policy solutions to promote local economic development, with wind energy development being part of the solution [30]. In this study, we do not have a clear hypotheses regarding the direction of the relationship between unemployment rate and wind capacity. We include it as an important control variable.

\subsection{Unexplored Wind Potential}

Unexplored wind potential measures the amount of unexplored wind energy in a province. It can be expected that higher unexplored wind energy potential is associated with stronger motivations for faster wind power deployment and utilization.

A set of control variables, including per capita income and population density, are also considered in the analysis. Per capita income is measured as Disposable Personal Income, collected from the China Statistical Yearbook [1]. Population density is measured as persons per square kilometer, collected from the China Statistical Yearbook [1]. A summary of variables, measurements, and data sources is presented in Table 3.

Table 3. Data sources.

\begin{tabular}{llll}
\hline Variables & Measures & $\begin{array}{l}\text { Predicted } \\
\text { Relationship }\end{array}$ & Data Sources \\
\hline Wind capacity & $\begin{array}{l}\text { Annual cumulative wind installation from } \\
\begin{array}{l}2001 \text { to } 2012 \text { in five Ethnic autonomous } \\
\text { regions, four centrally-controlled } \\
\text { municipalities and 22 provinces }\end{array}\end{array}$ & $\begin{array}{l}\text { Dependent variable } \\
\text { Wind policy }\end{array}$ & $\begin{array}{l}\text { Chinese Wind } \\
\text { Energy Association, } \\
\text { CWEA }\end{array}$ \\
\hline "0" otherwise
\end{tabular}


Table 3. Cont.

\begin{tabular}{llll}
\hline Variables & Measures & $\begin{array}{l}\text { Predicted } \\
\text { Relationship }\end{array}$ & Data Sources \\
\hline Unemployment rate & Unemployment rate (\%) & Control & $\begin{array}{l}\text { China Statistical } \\
\text { Yearbook [1] }\end{array}$ \\
\hline $\begin{array}{l}\text { Unexplored wind } \\
\text { potential }\end{array}$ & Unexplored theoretical potential (MW) & Control & $\begin{array}{l}\text { China Statistical } \\
\text { Yearbook [1] }\end{array}$ \\
\hline Per capita income & $\begin{array}{l}\text { Disposable Personal Income, DPI, } \\
\text { (RMB Yuan) }\end{array}$ & Control & $\begin{array}{l}\text { China Statistical } \\
\text { Yearbook [1] }\end{array}$ \\
\hline Population density & $\begin{array}{l}\text { Population density (person per square } \\
\text { kilometer) }\end{array}$ & Control & $\begin{array}{l}\text { China Statistical } \\
\text { Yearbook [1] }\end{array}$ \\
\hline
\end{tabular}

\section{Results and Discussion}

Table 4 presents descriptive statistics for the variables in this study. A series of tests have been performed to ensure that the assumptions of the fixed effect model are met, including the Hausman test, which favors the choice of fixed effect model. The standard errors are clustered robust standard errors. Time dummies could account for the impacts of the national renewable energy policies, such as the Renewable Energy Law.

Table 4. Descriptive statistics.

\begin{tabular}{cccccc}
\hline Variable & Observation & Mean & Standard Deviation & Min & Max \\
\hline Wind capacity & 324 & 624.21 & 1919.82 & 0 & $18,623.8$ \\
Wind policy & 324 & 0.15 & 0.36 & 0 & 1 \\
Energy plan & 324 & 0.27 & 0.44 & 0 & 1 \\
Pollution fee & 324 & $46,086.95$ & $45,800.11$ & 357 & 287,343 \\
SO $_{2}$ emissions & 324 & 72.14 & 46.35 & 0.1 & 200.30 \\
Per capita GDP & 324 & 2.25 & 1.71 & 0.29 & 9.13 \\
Unemployment rate & 324 & 3.71 & 0.69 & 1.2 & 6.9 \\
Unexplored wind potential & 324 & $118,278.8$ & $182,452.2$ & 7849.3 & $786,868.2$ \\
Per capita income & 324 & $13,311.02$ & 6348.30 & 5267.42 & $40,188.34$ \\
Population density & 324 & 2121.96 & 1393.40 & 56 & 6307 \\
\hline
\end{tabular}

\subsection{Wind Energy Policy and Energy Plan}

The results of the analysis are very supportive of the hypotheses discussed earlier, as presented in Table 5. Because the dependent variable is log-transformed, the percent change is used in the interpretation of the coefficients in the model. The first set of results to be discussed is policy variables. This study measures provincial energy policies with two dummy variables, one for wind energy policy and the other for the general energy plan. The coefficient for wind energy policy, measuring whether there is a wind energy development policy in the province, is positive and statistically significant at the 0.01 level. This means that wind capacity on average increases by $70 \%$ with the adoption of wind policy over time. This indicates that wind policy, as the most important province-level wind energy policy, is driving the growth of wind capacity in the provinces. As the compliance ratio of wind policy is very high in most provinces over the years, the positive impacts of wind policy on wind capacity growth is within expectations.

One additional variable, "general energy plan", is used to measure the presence of the province-level general energy policy. The coefficient for the variable indicating the impact of a province level energy plan on its provincial wind capacity development is significant. Specifically, the magnitude of the coefficient means that the installed wind capacity in a given province increases by $48.5 \%$ on average with the adoption of a general energy plan, controlling for other factors. This confirms the hypothesis presented earlier that a general energy plan could have significant local policy 
impacts, and that implementing an energy plan would greatly benefit the survival and growth of the wind industry.

Table 5. Fixed Effect model of drivers of wind development in Chinese provinces. Dependent variable: wind generation capacity in megawatts (log-transformed).

\begin{tabular}{ccc}
\hline Variables & Coefficient & Standard Errors \\
\hline Wind policy & $0.701^{* * *}$ & 0.269 \\
Energy plan & $0.485^{* *}$ & 0.232 \\
Pollution fee & $0.515^{* *}$ & 0.239 \\
$\mathrm{SO}_{2}$ emissions & $-0.844^{* *}$ & 0.369 \\
Per capita GDP & -0.280 & 0.283 \\
Unemployment rate & 0.025 & 0.202 \\
Unexplored wind potential & -6.779 & 4.255 \\
Per capita income & $0.346^{* * *}$ & 0.063 \\
Population density & 0.078 & 0.078 \\
Constant & 70.802 & 46.073 \\
Observation & 324 & - \\
Province Fixed Effect & Yes & - \\
Year Fixed Effect & Yes & - \\
R-squared (within) & 0.772 & - \\
\hline \multirow{2*}{*}{$p<0.05 ;{ }^{* * *} p<0.01$ (two-tailed). }
\end{tabular}

The significance of both wind energy policy and general energy plan at the provincial level confirms the importance of studying energy policy at the provincial level. Given the overwhelming dominance of extant studies focusing on national-level energy policies, more empirical studies are needed to investigate the effect and mechanism of provincial energy policies.

\subsection{Energy and Emission Markets}

Three variables were included to measure energy and emission market conditions: $\mathrm{SO}_{2}$ emissions, pollution fees, and unexplored wind potential. The impact of $\mathrm{SO}_{2}$ emissions on wind capacity growth was hypothesized to be negative, with more $\mathrm{SO}_{2}$ emissions associated with slower wind capacity growth. The result shows that the coefficient for $\mathrm{SO}_{2}$ emissions in the provinces is negative and statistically significant at the 0.05 level. This means that there is an eight percent decrease in the amount of wind capacity associated with a one percent increase in the province $\mathrm{SO}_{2}$ emissions, controlling for other factors. This result is consistent with information found in the literature that posited that carbon-intensive interest groups may negatively affect wind power growth.

The coefficient for pollution fees in the provinces is statistically significant at the 0.05 level. To interpret the coefficient, there is a five percent increase in the amount of wind capacity associated with a one percent increase in the provincial pollution fee collected, controlling for other factors. The other variable of the energy and emission market conditions is unexplored wind potential. The result of the analysis indicates that this variable is negative but insignificant. This might indicate that unexplored wind potential is a necessary but not a sufficient condition for wind power development.

\subsection{Economic and Social Environments}

Regarding the influence of economic and social circumstances, the discussion is now focused on the results for per capita income, per capita GDP, unemployment rate, and population density. The coefficient of population density was insignificant, indicating that there is no linear relationship between provincial population density and wind capacity growth. The positively significant coefficient means that per capita income is positively correlated with wind capacity growth. To put the size of the coefficient into perspective, as the amount of per capita income increases by 1 percent, the amount of installed wind capacity increases by 3.4 percent. 
The results for per capita GDP and unemployment rate are either insignificant or in opposite directions, suggesting a counter cyclical pattern of wind capacity growth. The size of electricity generation, electricity consumption, electricity price, and research and development input of funds in the provinces were included as controls, but none of them were significant in the results.

\section{Conclusions and Policy Implications}

Wind energy has become a fast-growing industry in China in the last decade. The development of the wind energy industry presents interesting policy questions. In the context of China, provincial policies were designed and implemented to stimulate the growth of wind power. This paper examines factors driving the growth of wind power capacity in the provinces, especially the impacts of provincial wind energy policies. A fixed-effect panel data statistical analysis is estimated with a longitudinal data set. With an R-squared value of $77.2 \%$, the overall statistical model explains $77.2 \%$ of the variation in the installed wind energy capacity in the Chinese provinces-a very strong model fit. The results reveal that the adoption of wind energy policies and the adoption of a general energy plan at the provincial level are having positive effects on the growth of wind capacity in Chinese provinces. Specifically, with the adoption of wind policy over time, the installed wind power capacity increases by $70 \%$. Similarly, the adoption of a general energy plan also leads to a $48.5 \%$ increase in wind generation capacity on average over time. The strong and positive policy-induced effects on the growth of renewables mirrors the findings from other national contexts on the research on Renewable Portfolio Standards $[4,26]$. The provincial wind energy policies serve as de facto renewable portfolio standards in setting the goals for renewable energy development, especially wind power.

Multiple policy implications can be drawn from this analysis. First, it is essential to maintain and strengthen current wind energy legislation to keep the strong momentum of wind capacity development in the provinces. As shown in this analysis, a province with wind policies is more likely to have a strong and robust wind capacity and relatively stable growth trajectories over time. The important policy implication of this study lies in the fact that effective wind power development in China is not only driven by implementing policies designed by the central government, but that provincial and local governments have a critical role to play in the process. This study demonstrated that substantial policy commitment is needed for provinces without such wind power policies, in order to speed up the development of wind energy.

Second, more aggressive provincial policies are needed to coordinate wind policies for grid connections. Ideally, the best solution is a national wind power grid legislation. Given that the central government of China has failed to pass national wind power grid legislation, provincial governments need to take policy actions to reduce the barriers for newly installed wind capacity to get connected to the grid. Given the widespread concern over provincial governments' restrictions on wind power's right to access to the grid, the best solution is to design and implement province-level grid connection policies to make a stronger commitment to wind power development.

Third, interconnection standards are needed to facilitate the utilization of existing wind power capacity. When comparing the wind power policies in the United States, Germany, and China, we find that the US has put into place strong policy guidelines on the interconnection standards between distributed generation and the electricity grid, and that Germany has been successful in making full use of its feed-in-tariff. Both interconnection standards and feed-in-tariff call for equal treatment of the renewable energy generators. The policy implication for China is that both national government and provincial governments should consider drafting rules facilitating the interconnections of distributed wind power generators to the electricity grid.

Acknowledgments: We would like to thank the two anonymous reviewers for the helpful comments.

Author Contributions: Xiaogang Zhang collected data, conducted quantitative data analysis and wrote the initial draft. Dong Wang contributed to writing and revising the introduction and discussions. Yuanhao Liu contributed to writing and revising the literature review section, and reformatting the references. Hongtao Yi 
proposed the original research idea and research design, contributed to data collection, wrote conclusion sections, and revised the whole draft.

Conflicts of Interest: The authors declare no conflicts of Interests.

\section{References}

1. China Statistics Bureau. China Statistical Yearbook, 2012; China Statistics Bureau: Beijing, China, 2012.

2. Zheng, S.; Yi, H.; Li, H. The impacts of provincial energy and environmental policies on air pollution control in China. Renew. Sustain. Energy Rev. 2015, 49, 386-394. [CrossRef]

3. Wu, J.; Zhang, P.; Yi, H.; Qin, Z. What Causes Haze Pollution? An Empirical Study of PM 2.5 Concentrations in Chinese Cities. Sustainability 2016, 8, 132. [CrossRef]

4. Yi, H.; Feiock, R.C. Renewable energy politics: Policy typologies, policy tools, and state deployment of renewables. Policy Stud. J. 2014, 42, 391-415. [CrossRef]

5. Yi, H.; Liu, Y. Green economy in China: Regional variations and policy drivers. Glob. Environ. Chang. 2015, 31, 11-19. [CrossRef]

6. Zhao, X.; Li, S.; Zhang, S.; Yang, R.; Liu, S. The effectiveness of China's wind power policy: An empirical analysis. Energy Policy 2016, 95, 269-279. [CrossRef]

7. Liao, Z. The evolution of wind energy policies in China (1995-2014): An analysis based on policy instruments. Renew. Sustain. Energy Rev. 2016, 56, 464-472. [CrossRef]

8. Shen, J.; Luo, C. Overall review of renewable energy subsidy policies in China-Contradictions of intentions and effects. Renew. Sustain. Energy Rev. 2015, 41, 1478-1488. [CrossRef]

9. Fang, Y.; Li, J.; Wang, M. Development policy for non-grid-connected wind power in China: An analysis based on institutional change. Energy Policy 2012, 45, 350-358. [CrossRef]

10. Zhang, S.; Andrews-Speed, P.; Zhao, X. Political and institutional analysis of the successes and failures of China's wind power policy. Energy Policy 2013, 56, 331-340. [CrossRef]

11. Wang, Z.; Qin, H.; Lewis, J.I. China's wind power industry: Policy support, technological achievements, and emerging challenges. Energy Policy 2012, 51, 80-88. [CrossRef]

12. Zhao, Y.; Hao, L.; Wang, Y. Development strategies for wind power industry in Jiangsu Province, China: Based on the evaluation of resource capacity. Energy Policy 2009, 37, 1736-1744. [CrossRef]

13. Dai, Y.; Xue, L. China's policy initiatives for the development of wind energy technology. Clim. Policy 2014, 15, 30-57. [CrossRef]

14. Yang, M.; Patiño-Echeverri, D.; Yang, F. Wind power generation in China: Understanding the mismatch between capacity and generation. Renew. Energy 2011, 41, 145-151. [CrossRef]

15. Lu, X.; McElroy, M.B.; Nielsen, C.P.; Chen, X.; Huang, J. Optimal integration of offshore wind power for a steadier, environmentally friendlier, supply of electricity in China. Energy Policy 2013, 62, 131-138. [CrossRef]

16. Li, L.; Tan, Z.; Wang, J.; Xu, J.; Cai, C.; Hou, Y. Energy conservation and emission reduction policies for the electric power industry in China. Energy Policy 2011, 39, 3669-3679. [CrossRef]

17. Lema, A.; Ruby, K. Between fragmented authoritarianism and policy coordination: Creating a Chinese market for wind energy. Energy Policy 2007, 35, 3879-3890. [CrossRef]

18. Yang, M.; Nguyen, F.; de T'Serclaes, P.; Buchner, B. Wind farm investment risks under uncertain CDM benefit in China. Energy Policy 2010, 38, 1436-1447. [CrossRef]

19. Zhao, X.; Wang, F.; Wang, M. Large-scale utilization of wind power in China: Obstacles of conflict between market and planning. Energy Policy 2012, 48, 222-232. [CrossRef]

20. Liu, X. The value of holding scarce wind resource-A cause of over investment in wind power capacity in China. Energy Policy 2013, 63, 97-100. [CrossRef]

21. Zhang, X.; Chang, S.; Huo, M.; Wang, R. China's wind industry: Policy lessons for domestic government interventions and international support. Clim. Policy 2009, 9, 553-564. [CrossRef]

22. Lam, J.C.K.; Woo, C.K.; Kahrl, F.; Yu, W.K. What moves wind energy development in China? Show me the money! Appl. Energy 2013, 105, 423-429. [CrossRef]

23. Zhao, X.; Zhang, S.; Zou, Y.; Yao, J. To what extent does wind power deployment affect vested interests? A case study of the Northeast China Grid. Energy Policy 2013, 63, 814-822. [CrossRef] 
24. Ma, T.; Yang, H.; Lu, L. A feasibility study of a stand-alone hybrid solar-wind-battery system for a remote island. Appl. Energy 2014, 121, 149-158. [CrossRef]

25. Ma, T.; Østergaard, P.A.; Lund, H.; Yang, H.; Lu, L. An energy system model for Hong Kong in 2020. Energy 2014, 68, 301-310. [CrossRef]

26. Carley, S. State Renewable Energy Electricity Policies: An Empirical Evaluation of Effective-ness. Energy Policy 2009, 37, 3071-3081. [CrossRef]

27. Sarzynski, A.; Larrieu, J.; Sharimali, G. The impact of state financial incentives on market deployment of solar technology. Energy Policy 2012, 46, 550-557. [CrossRef]

28. Shrimali, G.; Jenner, S. The impact of state policy on deployment and cost of solar photovoltaic technology in the U.S.: A sector-specific empirical analysis. Renew. Energy 2013, 60, 679-690. [CrossRef]

29. Yi, H. Clean energy policies and green jobs: An evaluation of green jobs in U.S. metropolitan areas. Energy Policy 2013, 56, 644-652. [CrossRef]

30. Lyon, T.P.; Yin, H. Why Do States Adopt Renewable Portfolio Standards? An Empirical Investigation. Energy J. 2010, 31, 133-157. [CrossRef]

(C) 2016 by the authors; licensee MDPI, Basel, Switzerland. This article is an open access article distributed under the terms and conditions of the Creative Commons Attribution (CC-BY) license (http://creativecommons.org/licenses/by/4.0/). 